\title{
Toosendanin suppresses oncogenic phenotypes of human gastric carcinoma SGC-7901 cells partly via miR-200a-mediated downregulation of $\beta$-catenin pathway
}

\author{
GE WANG, YAN-XIA HUANG, RUI ZHANG, LI-DAN HOU, HUI LIU, \\ XIAO-YU CHEN, JIN-SHUI ZHU and JING ZHANG \\ Department of Gastroenterology, Shanghai Jiao Tong University Affiliated \\ Sixth People's Hospital, Shanghai 200233, P.R. China
}

Received May 27, 2017; Accepted July 28, 2017

DOI: 10.3892/ijo.2017.4139

\begin{abstract}
Aberrant activation of $\beta$-catenin signaling due to low expression of miR-200a is found in gastric carcinoma $(\mathrm{GC})$ tissues promoting GC evolution. Toosendanin (TSN) has exhibited antitumor effects on various human cancer cells, but its influence on GC is largely unidentified. The potential roles of TSN on GC cells were examined and it was found that TSN inhibited growth, migration, invasion and TGF- $\beta 1$ induced epithelial-mesenchymal transition (EMT) and induced cell cycle arrest and apoptosis in SGC-7901 cells which were most sensitive to TSN among various GC cell lines. TSN also inactivated $\beta$-catenin pathway in SGC-7901 cells and the above effects were reversed following induction of $\beta$-catenin overexpression. Moreover, TSN facilitated the level of miR-200a which targets $\beta$-catenin and miR-200a silencing attenuated the antitumor effects of TSN on SGC-7901 cells. Nonetheless, knockdown of miR-200a did not relieve the suppressive effects of TSN on p-AKT, p-ERK and p-GSK3 $\beta$ which were upstream regulators of $\beta$-catenin. In addition, TSN administration inhibited growth and liver metastasis of orthotopically implanted SGC-7901 tumors in vivo through miR-200a-mediated $\beta$-catenin pathway. Our data suggest that TSN may suppress oncogenic phenotypes of human GC cells partly via miR-200a/ $\beta$-catenin axis. Hence, TSN may have a promising chemotherapeutic activity for GC therapy.
\end{abstract}

Correspondence to: Professor Jin-Shui Zhu or Dr Jing Zhang, Department of Gastroenterology, Shanghai Jiao Tong University Affiliated Sixth People's Hospital, 600 Yishan Road, Shanghai 200233, P.R. China

E-mail: zhujs1803@163.com

E-mail: jing5522724@163.com

Key words: gastric carcinoma, toosendanin, $\beta$-catenin, miR-200a, epithelial-mesenchymal transition

\section{Introduction}

Gastric carcinoma (GC), the fifth most common malignancy and second leading cause of cancer-related death worldwide, remains an important public health challenge especially in East Asian countries including China $(1,2)$. Though therapeutic strategies have been improved in recent years, GC still has low 5-year survival rate owing to late diagnosis, high relapse and metastatic rates, multidrug resistance, and severe toxicities $(3,4)$. The process of GC growth and metastasis is complex and involves a large number of oncogenes and tumor suppressor genes. As a result, development of more effective chemotherapeutic agents for GC therapy is urgent.

Wnt/ $\beta$-catenin signaling pathway, or the canonical Wnt pathway, plays a fundamental role in many human physiological processes as well as tumor progression (5). The abnormality of Wnt/ $\beta$-catenin pathway is a common feature in many human cancers and promotes cell proliferation and metastasis (6-11). Particularly, aberrant activation of $\beta$-catenin signaling is found in $\sim 30-50 \%$ of GC tissues and various gastric cancer cell lines and indicates poor prognosis (12-14). Moreover, via $\beta$-catenin pathway, $H$. pylori induced gastric stem cell generation and expansion, promoting gastric cancer initiation and progression (15). $\beta$-catenin, the crucial molecule in $\beta$-catenin pathway and frequently detected in GC, promotes the transcription of several oncogenic target genes related to cancer evolution $(16,17)$. Epithelial-mesenchymal transition (EMT), by which epithelial cells lose their polarity and cell-cell adhesion and acquire the properties of mesenchymal cells, plays a pivotal role in cancer migration, invasion and metastasis $(18,19)$. $\beta$-catenin pathway is also one of the major signalings involved in EMT and then plays a critical role in metastasis (20). Consequently, $\beta$-catenin pathway has emerged as a promising target for GC therapy.

MicroRNAs (miRNAs) are a family of small ( 22 nucleotides in length) and endogenous noncoding RNAs processed from double-stranded hairpin precursors (21). Several studies showed that miRNAs have a capacity to act as tumor suppressors and their deregulation is associated with initiation and 
progression of many human cancers $(22,23)$. The miR-200 family, comprising 5 members (miR-200a, -200b, -200c, -141 and -429$)$, is found significantly downregulated in prostate cancer, breast cancer, lung adenocarcinoma and GC and may become a potential prognostic predictor of GC (24-29). Downregulation of miR-200 family also leads to reduced E-cadherin expression, which is a crucial step in the carcinogenesis of EBV-associated GC (30). miR-200a shows anti-oncogenic features in many cancers including GC (31-33). Elevated miR-200a in SGC-7901 cells inhibited cell growth and invasion and induced G0/G1 phase arrest (33). More importantly, recent studies demonstrated that miR-200a inhibited GC growth and EMT through suppressing $\beta$-catenin signaling while miR-200b and miR-200c, two additional members in miR-200 family, showed no impact on $\beta$-catenin expression (33-35). Accordingly, targeting miR-200a and $\beta$-catenin is a promising therapeutic option for GC.

Toosendanin (TSN), as shown in Fig. 1A, is a triterpenoid extracted from the bark or fruits of Melia toosendan Sieb et Zucc, which mainly grows in China and India. Mounting evidence has indicated that TSN plays a variety of biological activities including analgesic, insecticidal and anti-inflammatory functions (36). Antitumor effect is another important property of TSN which can kill multiple human cancer cells in vitro with half maximal inhibitory concentration $\left(\mathrm{IC}_{50}\right)$ ranging from 5.4 to $900 \mathrm{nM}$ (37-39). In addition, TSN can induce tumor apoptosis by regulating mitochondrial pathway in vitro and suppress hepatocellular carcinoma growth in BALB/C mice in vivo $(36,37)$. Our previous study documented that TSN inhibited growth and induces apoptosis in colorectal cancer (CRC) cells through suppression of AKT/ GSK-3 $\beta / \beta$-catenin pathway (40).

Nevertheless, effects of TSN on GC and their sophisticated molecular mechanisms have not been reported before. In the present study, we revealed antitumor effects of TSN on GC and their novel mechanism. The results demonstrated that TSN inhibits GC growth, invasion, migration, EMT and liver metastasis in vitro and in vivo by stimulating expression of miR-200a which attenuates activation of $\beta$-catenin pathway. Knockdown of miR-200a or raising $\beta$-catenin level in GC cells weakened the above function of TSN. Our data suggested that suppression of GC growth and metastasis by TSN may be associated with miR-200a-mediated downregulation of $\beta$-catenin pathway, thereby showing a promising preclinical activity of TSN for GC therapy.

\section{Materials and methods}

Drugs and reagents. TSN (purity $\geq 99 \%$ ) was purchased from Shanghai Yuanye Biotechnology Co., Ltd. (Shanghai, China). 3-(4,5)-dimethylthiazol(-2-yl)-2,5-diphenyltetrazolium bromide (MTT), Annexin V/propidium iodide (PI) apoptosis detection kit, cell cycle analysis kit and enhanced chemiluminescence (ECL)-Plus/kit were all from KeyGen Biotech Co., Ltd. (Nanjing, China). TRIzol reagent were from Invitrogen (Carlsbad, CA, USA). SYBR Green Master Mixture was obtained from Takara (Otsu, Japan). miScript Reverse Transcription kit and miScript SYBP Green PCR kit were all from Qiagen (Japan). $\beta$-catenin, c-Myc, cyclin D1, Bcl-2, MMP-9, AKT, p-AKT(Ser $\left.{ }^{473}\right)$, GSK3 $\beta$, p-GSK3 $\beta\left(\operatorname{Ser}^{9}\right)$ and $\beta$-actin polyclonal antibodies were all from ABclonal Biotech Co. (Wuhan, China). Histone H3, E-cadherin, N-cadherin and vimentin monoclonal antibodies were all from Cell Signaling Technology (Beverly, MA, USA). ERK1/2 and p-ERK1/2 $\left(\mathrm{Thr}^{202} / \mathrm{Tyr}^{204}\right)$ polyclonal antibodies were both from Hangzhou HuaAn Biotechnology Co., Ltd. (Hangzhou, China).

Cell culture. Human GC cell lines MGC-803, BGC-823, HGC-27, AGS, SGC-7901 and MKN-45 and normal human gastric epithelial cells GES-1 were obtained from the Type Culture Collection, Chinese Academy of Sciences (Shanghai, China), cultured in RPMI-1640 medium supplemented with $10 \%$ heat-inactivated fetal bovine serum (FBS), $100 \mathrm{U} / \mathrm{ml}$ penicillin and $100 \mu \mathrm{g} / \mathrm{ml}$ streptomycin and in a humidified atmosphere containing $5 \% \mathrm{CO}_{2}$ at $37^{\circ} \mathrm{C}$.

Vector construction and cell infection. Lentivirus-mediated $\beta$-catenin overexpression vector (LV-CTNNB1), negative control vector (CON238), lentivirus-mediated hsa-miR-200a-3p knockdown vector (LV-hsa-miR-200a-3p-inhibition) and negative control vector (CON137) were all from GeneChem Co., Ltd. (Shanghai, China). The correct sequences and insertions were confirmed by DNA sequencing. Transfection was performed according to the manufacturer's instructions. On the day of vector transduction, SGC-7901 cells were cultured at $5 \times 10^{4}$ cells/well in 24-well plates containing serum-free medium with polybrene $(5 \mathrm{mg} / \mathrm{ml})$. At $50 \%$ confluence, cells were transfected with recombinant experimental virus or control virus at the optimal MOI (multiplicity of infection) of 50 , and cultured at $37^{\circ} \mathrm{C}$ and $5 \% \mathrm{CO}_{2}$ for $4 \mathrm{~h}$. Then supernatant was discarded and medium containing serum was added. Positive and stable transfectants were selected and expanded for further study.

Cell proliferation assay. Cell proliferation was analyzed using the MTT assay. Briefly, cells were cultured in 96-well plates at a density of $5 \times 10^{3}$ cells/well. After adhering to the plate surface, cells were treated with TSN of different doses for various times, followed by $20 \mu \mathrm{l}$ MTT $(5 \mathrm{mg} / \mathrm{ml})$ incubation for further $4 \mathrm{~h}$ and subsequent $150 \mu \mathrm{l}$ DMSO dissolution for $5 \mathrm{~min}$. The optical densities (ODs) were measured at $570 \mathrm{~nm}$ using an enzyme immunoassay analyzer (Bio-Rad, Hercules, CA, USA). The cell proliferation inhibition rates were calculated using the following formula: 1 - OD (experiment) / OD (control). The experiment was performed in triplicate.

Flow cytometric analysis. Annexin V/PI apoptosis detection kit was used to detect cell apoptosis. Briefly, cells $\left(1 \times 10^{6}\right)$ treated with or without TSN for $48 \mathrm{~h}$ were harvested and suspended in binding buffer according to the instruction of the apoptosis kit. Approximately $5 \mu \mathrm{l}$ Annexin $\mathrm{V}$ and $5 \mu \mathrm{l} \mathrm{PI}$ were then added to the fixed cells for $20 \mathrm{~min}$ in darkness at room temperature. Then, Annexin V binding buffer was added to the mixture before analysis by fluorescent activated cell sorting (FACS) on a flow cytometer. Three separate experiments were performed for each clone.

For cell cycle distribution analysis, cells were incubated in serum-free medium for $24 \mathrm{~h}$ followed by treatment with TSN for another $48 \mathrm{~h}$. Then cells were trypsinized, washed with PBS, fixed with $75 \%$ cold ethanol overnight at $4^{\circ} \mathrm{C}$ and washed 
Table I. Sequences of the primers used in the real-time PCR amplifications.

\begin{tabular}{lll}
\hline Gene primer & \multicolumn{1}{c}{ Forward $\left(5^{\prime}-3^{\prime}\right)$} & \multicolumn{1}{c}{ Reverse (5'-3') } \\
\hline miR-200a & AACACTGTCTGGTAACGATGTCGT & miScript SYBP Green PCR Kit Universal primer \\
U6 & GGATTAACGATACAGAGAAGATT & miScript SYBP Green PCR Kit Universal primer \\
AKT & GGGACAGAGGAGCAAGGT & CGACAGCGGAAAGGTTAA \\
ERK & TACACCAACCTCTCGTACATCG & CATGTCTGAAGCGCAGTAAGATT \\
GSK-3 $\beta$ & GACTAAGGTCTTCCGACCCC & AAGAGTGCAGGTGTGTCTCG \\
$\beta$-catenin & GGCCATATCCACCAGAGTGAA & GCCAATGGCTTGGAATGAGA \\
c-myc & CACCAGCAGCGACTCTGA & GATCCAGACTCTGACCTTTGC \\
Cyclin D1 & GAAGTTGCAAAGTCCTGGAGC & ATGGTTCCACTTCGCAGCA \\
Bcl-2 & TCGCCCTGTGGATGACTGAG & CAGAGTCTTCAGAGACAGCCAGGA \\
MMP-9 & CGCGCTGGGCTTAGATCAT & GGTGCCGGATGCCATTC \\
ACTB & GGCCAACCGCGAGAAGAT & CGTCACCGGAGTCCATCA \\
\hline
\end{tabular}

with PBS again. Afterwards, the fixed cells were stained with PI in the presence of RNase A for $30 \mathrm{~min}$ in the dark. The samples were then analyzed on FACsort flow cytometer (Becton-Dickinson, Mountain View, CA, USA). The DNA content in cells could be read according to PI fluorescence. ModFit3.0 software (Verity Software House, Topsham, ME, USA) was used for cell cycle analysis. The experiment was performed in triplicate.

Transwell invasion and wound-healing assay. SGC-7901 cells were suspended in serum-free medium with or without TSN after starvation in serum-free medium for $24 \mathrm{~h}$. The suspension were then added to the upper chamber coated with Matrigel $(3.9 \mu \mathrm{g} / \mu \mathrm{l}, 80 \mu \mathrm{l})$, while the lower chamber was filled with RPMI-1640 medium containing $10 \%$ bovine serum. After 24-h incubation, the non-invaded cells on the upper side of the chamber were washed away and cells attached to the bottom were fixed with $75 \%$ alcohol and stained with crystal violet. The number of cells invading through the Matrigel were counted using microscope in three random fields of each group.

Cell migration was assessed by wound-healing assay. Briefly, the adherent cells in a 6 -well plate $\left(1 \times 10^{6} /\right.$ well) were wounded with a standard $200-\mu 1$ pipette tip to form a $1-\mathrm{mm}$ wide strip across the well. Then the wounded monolayers were washed twice with PBS before incubation in medium with or without TSN. After 48-h incubation, the wound closure was observed and photographed with a microscope.

$R N A$ extraction and $q R T-P C R$. Total RNA was extracted using TRIzol reagent (Invitrogen) according to the manufacturer's protocol. Total RNA $(1 \mu \mathrm{g})$ was used to synthesize cDNA by reverse transcription using M-MLV reverse transcriptase and cDNA amplification was performed using the Power SYBR Green Master Mix kit (for AKT, ERK, GSK3 $\beta$, $\beta$-catenin, c-Myc, cyclin D1, Bcl-2 and MMP-9). MiScript Reverse Transcription kit and miScript SYBP Green PCR kit were for miR-200a according to the manufacturer's instructions. The primer sequences are shown in Table I. The expression of human $\beta$-actin or U6 was used as internal control. Cycle threshold $(\mathrm{Ct})$ values were obtained graphically for the target genes, miR-200a, U6 and $\beta$-actin. $\Delta \mathrm{Ct}=\mathrm{Ct}$ (target genes or miR-200a) - Ct ( $\beta$-actin or U6). $\Delta \Delta \mathrm{Ct}=\Delta \mathrm{Ct}$ (experimental group) - $\Delta \mathrm{Ct}$ (control group). Data were analyzed using the comparative $\mathrm{Ct}$ method $\left(2^{-\Delta \Delta \mathrm{Ct}}\right)$. Each sample was tested in triplicate.

Western blot analysis. Cytoplasmic proteins were extracted with RIPA buffer and nuclear protein extraction was conducted using Nuclear Extraction kit (Life Technologies, Carlsbad, CA, USA). Protein concentrations were determined using Bradford assay and cell extracts were boiled for $5 \mathrm{~min}$ in loading buffer. Equal amount of proteins were separated on $12 \%$ sodium dodecyl sulfate polyacrylamide gel electrophoresis before translocation onto polyvinylidene fluoride (PVDF) membranes (Millipore, Billerica, MA, USA). Then the membranes were blocked with 5\% skim milk for $1 \mathrm{~h}$. The primary antibodies against AKT, p-AKT, ERK, p-ERK, GSK3 $\beta$, p-GSK3 $\beta, \beta$-catenin, histone H3, c-Myc, cyclin D1, Bcl-2 and MMP-9 were diluted according to the manufacturer's instructions and the membranes were incubated overnight at $4^{\circ} \mathrm{C}$. Afterwards, the membranes were washed three times followed by incubation in HRP-labeled goat anti-rabbit $\mathrm{IgG}$ secondary antibodies at a dilution ratio of 1:4,000 at room temperature for $1 \mathrm{~h}$. Immunodetection was performed with an ECL-Plus/kit.

In vivo orthotopic xenograft tumor model. All animals were purchased from Shanghai Laboratory Animal Center of Chinese Academy Sciences (Shanghai, China) and were adapted to cages with 12-h light/dark cycle in a temperaturecontrolled environment for study. SGC-7901 cells with or without transduction were subcutaneously injected and maintained by passage in the hypodermis of female BALB/c/nu/nu mice (4-5 weeks of age, 18-20 g). The female BALB/c/nu/nu mice (4-5 weeks of age, 18-20 g) were randomly divided into 4 groups ( $n=5 /$ group). Mice in groups 1 and 2 were orthotopically implanted in the stomach with subcutaneous GC tissue pieces formed by SGC-7901 cells without transduction while SGC-7901 cells transfected with LV-CTNNB1 
A

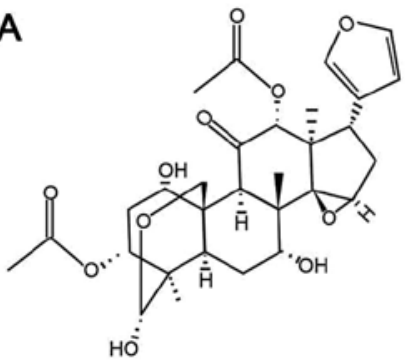

$\mathrm{E}$

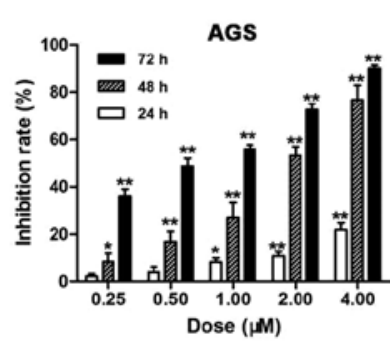

B

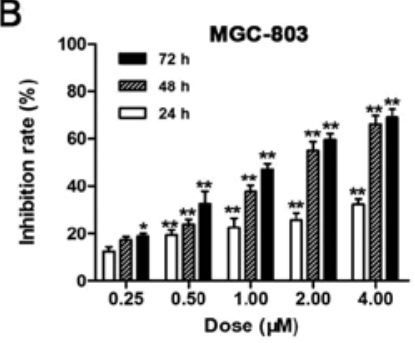

$\mathrm{F}$

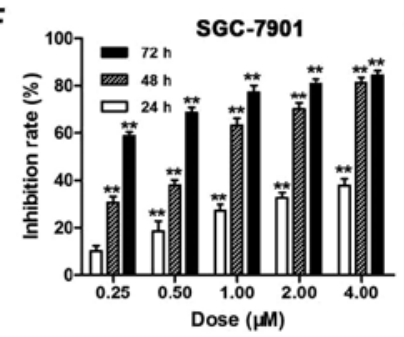

C

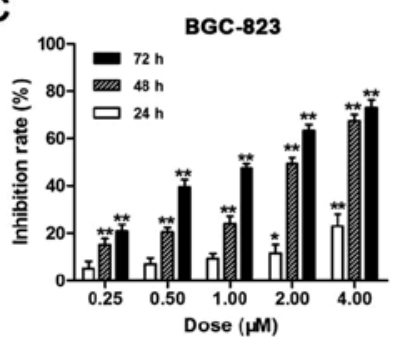

D

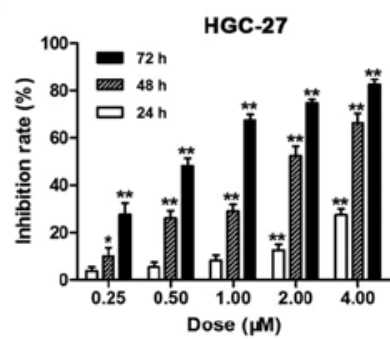

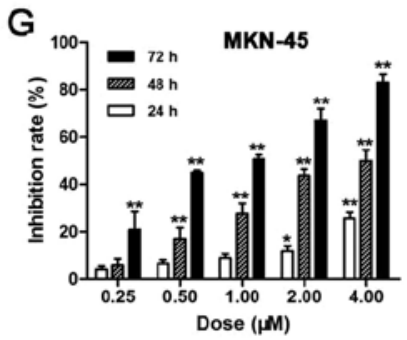

$\mathrm{H}$
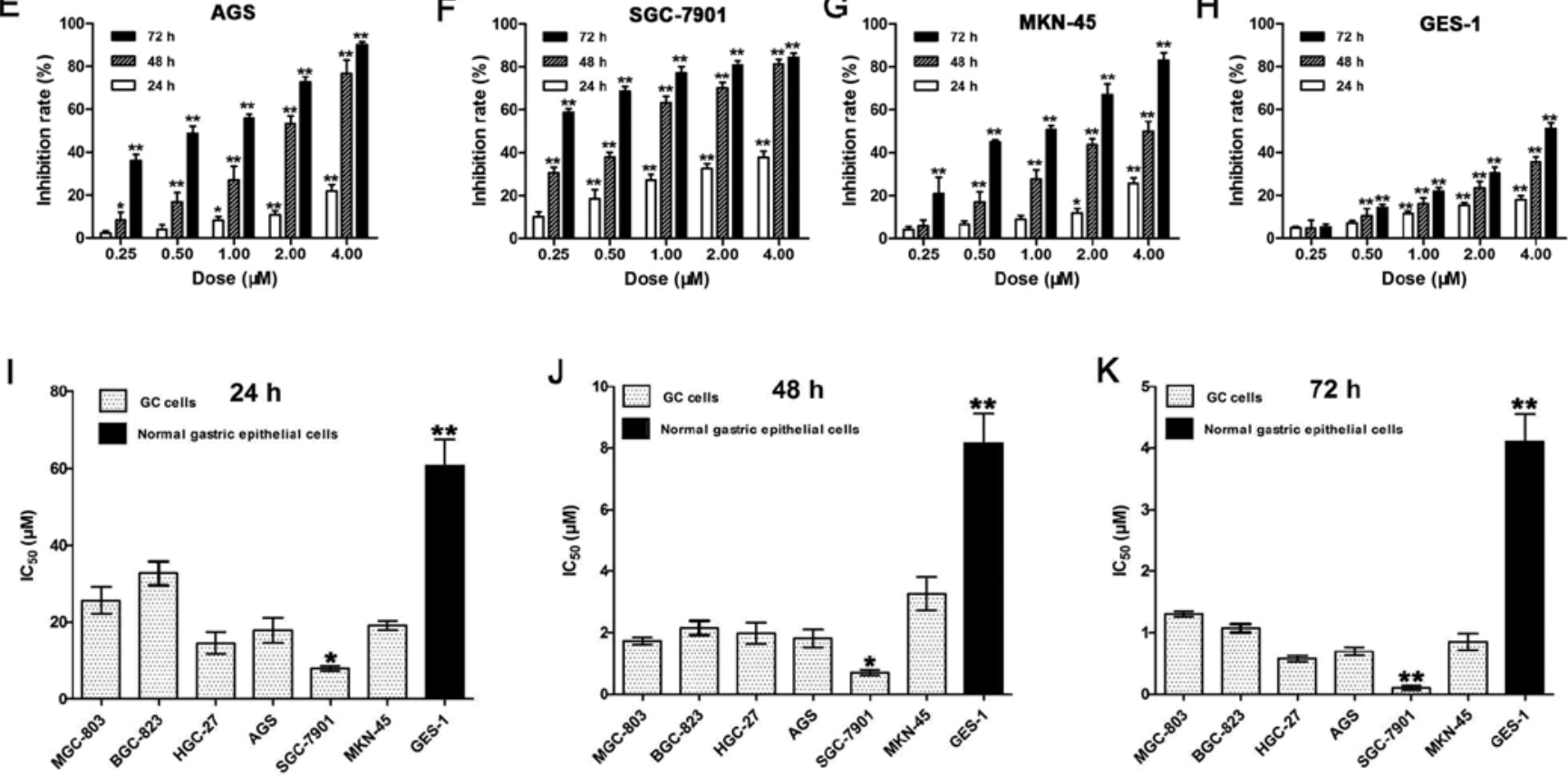

Figure 1. The chemical structure of toosendanin and inhibitory effects of TSN on the proliferation of human GC cell lines and GES-1 cells. (A) The molecular structural formula of toosendanin $\left(\mathrm{C}_{30} \mathrm{H}_{38} \mathrm{O}_{11}\right.$, molecular weight $\left.=574.63\right)$. $(\mathrm{B}-\mathrm{H})$ Inhibition rates of proliferation were determined by MTT assay and calculated using formula: 1 - OD (experiment) / OD (control). The cells treated by TSN $(0,0.25,0.5,1,2$ and $4 \mu \mathrm{M})$ for 24,48 and $72 \mathrm{~h}$ contained GC cell lines MGC-803 (B), BGC-823 (C), HGC-27 (D), AGS (E), SGC-7901 (F) and MKN-45 (G) as well as normal human gastric epithelial cell lines GES-1 (H). $(\mathrm{I}-\mathrm{K}) \mathrm{IC}_{50}(\mu \mathrm{M})$ of TSN on various human GC cell lines and GES-1 cells for $24 \mathrm{~h}(\mathrm{I}), 48 \mathrm{~h}(\mathrm{~J})$ and $72 \mathrm{~h}(\mathrm{~K})$ were calculated on the basis of inhibition rates. Data shown are statistical analysis of three independent experiments $\left({ }^{*} \mathrm{p}<0.05,{ }^{* *} \mathrm{p}<0.01\right)$.

or LV-hsa-miR-200a-3p inhibition belonged to groups 3 and 4 , respectively. Before sugery, the female mice were administered with rhabarber and glauber to further reduce the immunity and improve the rate of tumor formation. The surgical procedure of gastric orthotopic transplantation was performed as previously reported (41). Briefly, subcutaneous GC tissue pieces $(\sim 2.0 \mathrm{~cm} \times 2.0 \mathrm{~cm} \times 1.0 \mathrm{~cm})$ were harvested and minced into small pieces $\left(\sim 1 \mathrm{~mm}^{3}\right)$. The female nude mouse stomach was gently exteriorized via a left-side upper abdominal incision and one small tissue pocket in the middle wall of the greater curvature was cut. One tumor piece was placed into the pocket and fixed with a drop of medical tissue glue (gifts from Department of General Surgery, Shanghai Jiao Tong University Affiliated Shanghai Sixth People's Hospital, Shanghai, China). The stomach was then relocated into the abdominal cavity followed by the abdominal closure with 4-0 absorbable sutures. Seven days after surgery, TSN was dissolved in RPMI-1640 medium and intraperitoneally given to all mice in groups 2,3 and 4 at a dose of $0.20 \mathrm{mg} / \mathrm{kg} / \mathrm{day}$ and $0.2 \mathrm{ml}$ once every other day for 35 days. Meanwhile, the equal volume of RPMI-1640 medium was administered to mice in group 1 in the same way. All mice were sacrificed by cervical dislocation and dissected $24 \mathrm{~h}$ after the final medicine. The orthotopically implanted tumor tissues were removed from stomach and was measured with a caliper and calculated with the formula volume $=\left(\right.$ length $\mathrm{x}$ width $\left.{ }^{2}\right) / 2$. The metastatic nodules in each liver were observed and counted. All in vivo animal studies were approved by the Animal Ethics and Research Committee of Shanghai Jiao Tong University and in accordance with the Internal Biosafety and Bioethics Guidelines of School of Medicine, Shanghai Jiao Tong University.

Immunohistochemistry (IHC). Immunohistochemistry was performed to assay the expression of tissue proteins in $\beta$-catenin pathway. Briefly, the gastric tumor tissue slides were deparaffinized, rehydrated, antigen-retrieved (performed with $10 \mathrm{mM}$ sodium citrate buffer, $\mathrm{pH} 6.0$, at $90^{\circ} \mathrm{C}$ for $30 \mathrm{~min}$ ), blocked and antibody-incubated in turn. The slides were preincubated with $0.04 \%$ bovine serum albumin to block 

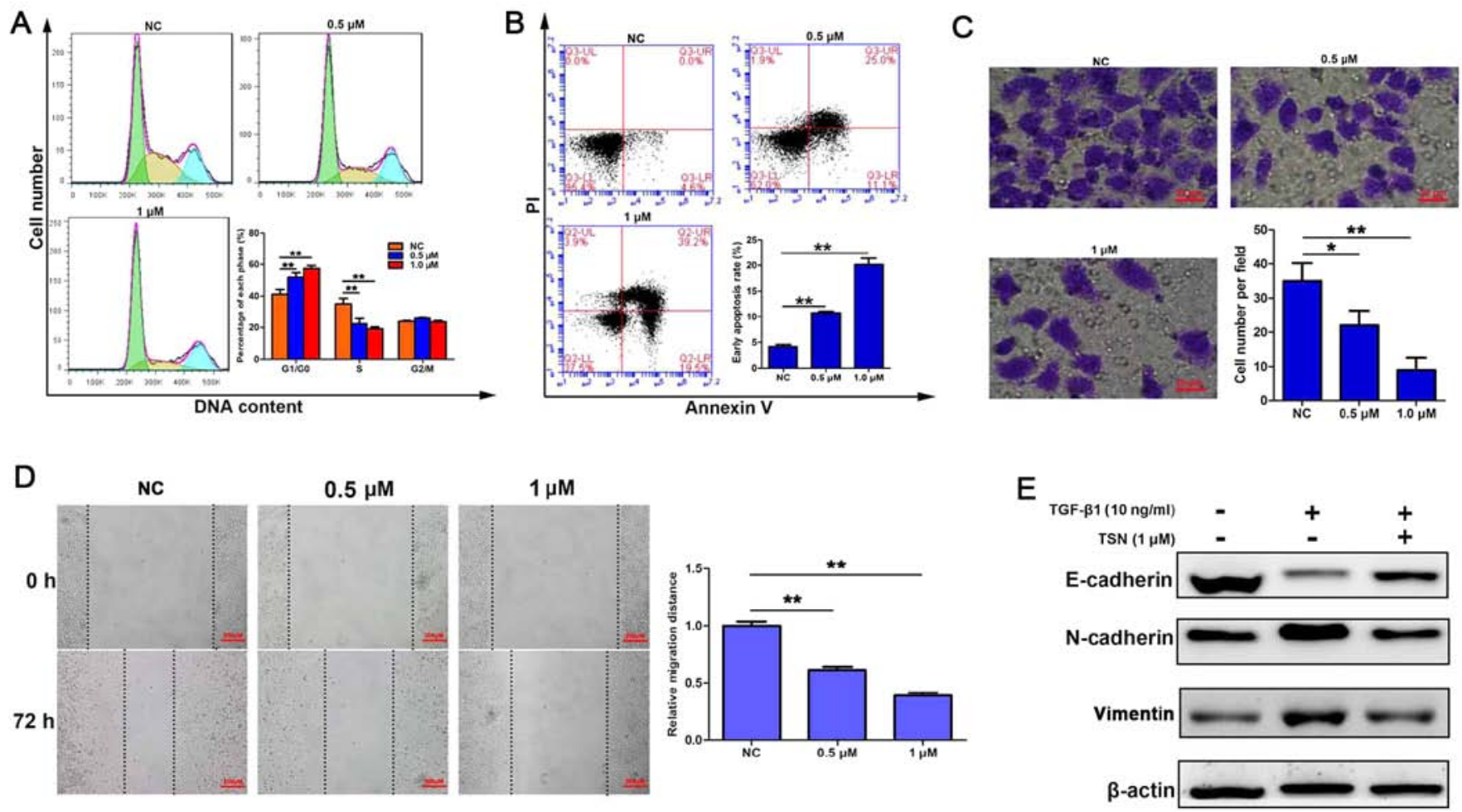

Figure 2. Effects of TSN on biological behavior of SGC-7901 cells. (A) Cell cycle of SGC-7901 cells treated by TSN $(0.5$ and $1 \mu \mathrm{M})$ for $48 \mathrm{~h}$ were determined by flow cytometric analysis. Data shown are a representative result of three independent experiments with statistical analysis. (B) Apoptosis rates of SGC-7901 cells treated by TSN $(0.5$ and $1 \mu \mathrm{M})$ for $48 \mathrm{~h}$ were determined by flow cytometric analysis. Data shown are a representative result of three independent experiments with statistical analysis. (C) Alterations of invasion were determined by Transwell assay. Representative images of invaded SGC-7901 cells after treatment of TSN $(0.5$ and $1 \mu \mathrm{M})$ for $48 \mathrm{~h}$ is shown (red scale bar, $20 \mu \mathrm{m})$. Data shown are a representative result of three independent experiments with statistical analysis. (D) Cell migration of SGC-7901 cells treated by TSN $(0.5$ and $1 \mu \mathrm{M})$ for $72 \mathrm{~h}$ was examined by the wound-healing assay (red scale bar, $200 \mu \mathrm{m})$. Data shown are a representative result of three independent experiments (left) with statistical analysis (right). (E) The effect of TSN $(1 \mu \mathrm{M})$ on the alteration of EMT marker expression induced by TGF- $\beta 1(10 \mathrm{ng} / \mathrm{ml})$ in SGC-7901 cells as determined by immunoblotting $\left({ }^{*} \mathrm{p}<0.05,{ }^{* *} \mathrm{p}<0.01\right)$.

non-specific binding. Subsequently, the slides were incubated with primary polyclonal antibodies (ABclonal Biotech Co., Ltd.) at a dilution of 1:200 overnight at $4^{\circ} \mathrm{C}$ and a secondary antibody (KeyGen Biotech Co.) at room temperature for $1 \mathrm{~h}$. Finally, the sections were stained with DAB (3,3-diaminobenzidine) and counterstained with hematoxylin. Images were visualized under a microscope (Olympus, Tokyo, Japan).

Statistical analysis. SPSS 20.0 was used for the statistical analysis. All of the values were recorded as the mean \pm standard deviation (SD). Independent-sample t-test and one-way analysis of variance (ANOVA) were used to analyze statistical differences of experimental data between two groups and more than two groups, respectively. Chi-square test $\left(\chi^{2}\right)$ test was used to compare the differences of proportions between two groups. Significance was defined as $\mathrm{p}<0.05$ or $\mathrm{p}<0.01$.

\section{Results}

Effects of TSN on proliferation of human GC cells and human normal gastric epithelial cells. We examined the effects of TSN on the viability of various GC cells (MGC-803, BGC-823, HGC-27, AGS, SGC-7901 and MKN-45) and normal human gastric epithelial cells (GES-1) using MTT assay. As shown in Fig. 1B-H, TSN produced marked proliferation inhibition of cells in a dose- and time-dependent manner. The calculated $\mathrm{IC}_{50}$ values on the basis of inhibition rates were $7.95 \pm 0.65$ to
$60.74 \pm 6.73 \mu \mathrm{M}(24 \mathrm{~h}), 0.70 \pm 0.09$ to $8.15 \pm 0.97 \mu \mathrm{M}(48 \mathrm{~h})$ and $0.11 \pm 0.04$ to $4.10 \pm 0.45 \mu \mathrm{M}(72 \mathrm{~h})($ Fig. $1 \mathrm{I}-\mathrm{K})$. Among these cell lines, SGC-7901 cells were most sensitive to the killing effect of TSN, whereas GES-1 was the least sensitive. The results indicate that at a certain dosage range, TSN might selectively kill human GC cells rather than normal human gastric epithelial cells.

TSN induces cell cycle arrest and apoptosis and inhibits invasion, migration and TGF- $\beta 1$-induced EMT in SGC-7901 cells. Since TSN exerted the most powerful cytotoxicity on SGC-7901 cells, we next used PI staining and flow cytometric analysis to determine if TSN influenced distribution of the cell cycle. As shown in Fig. 2A, the proportion of cells at G0/G1 phase increased while that at $\mathrm{S}$ phase decreased after treatment with TSN $(0.5$ and $1 \mu \mathrm{M})$ for $48 \mathrm{~h}$ in a dosedependent manner. Then Annexin V/PI double staining and flow cytometric analysis were performed to assess the rate of apoptosis. As indicated in Fig. 2B, after treating for $48 \mathrm{~h}$, TSN induced a dose-dependent increase of cells undergoing early apoptosis. Furthermore, invasion potential was determined by Transwell assay and the results showed that TSN suppressed cell invasive capacity also in a dose-dependent manner (Fig. 2C). The wound-healing assay confirmed the slower migration of SGC-7901 cells by TSN treatment (Fig. 2D). In addition, western blot analysis showed that expression of E-cadherin, which was an epithelial marker 
A

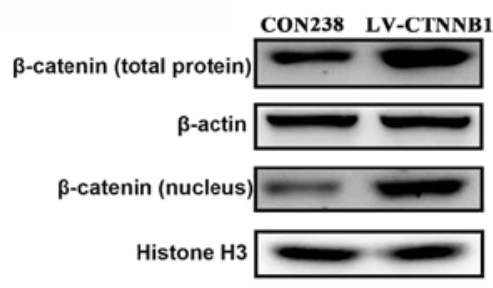

B

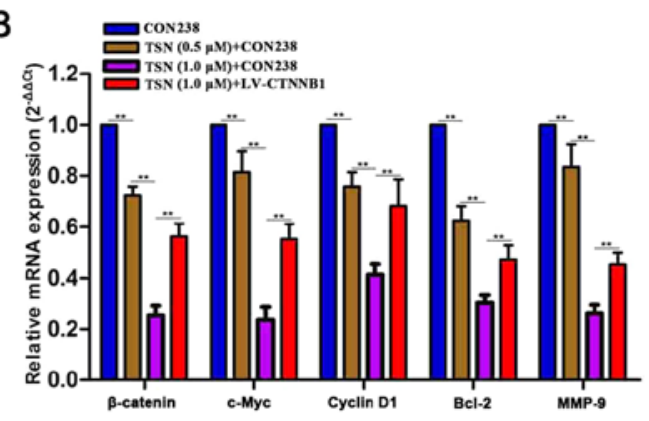

C

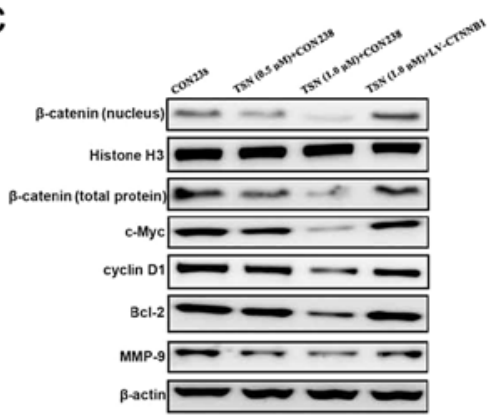

D

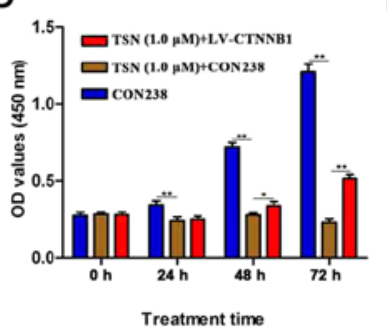

E

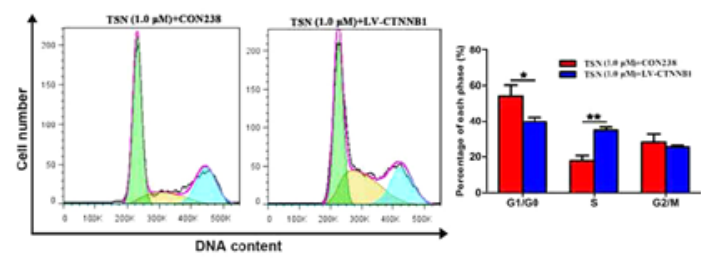

$\mathrm{F}$

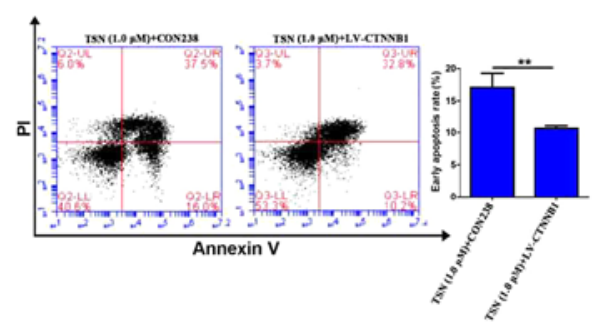

G

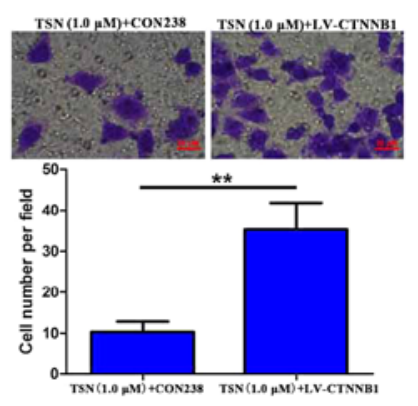

$\mathrm{H}$

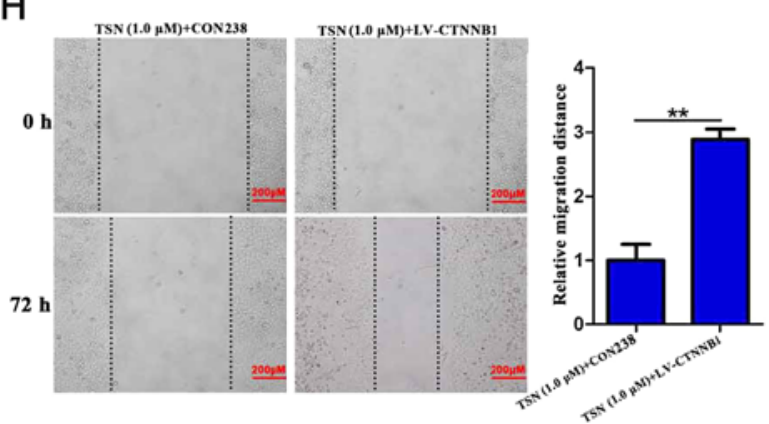

I

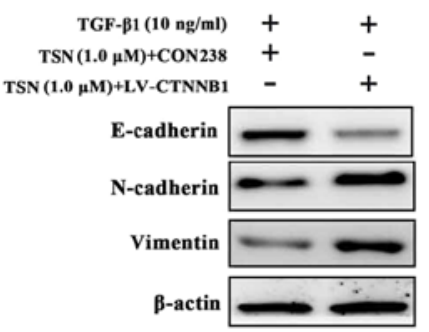

Figure 3. TSN has antitumor effects on SGC-7901 cells via suppressing $\beta$-catenin signaling. (A) Protein levels of $\beta$-catenin in total protein and nucleus in CON238 and LV-CTNNB1 groups were examined by immunoblotting. $\beta$-actin was used as the loading control for total protein and histone H3 for the nuclear fractions. (B and C) qRT-PCR and immunoblotting were performed to determined the mRNA (B) and protein (C) level of $\beta$-catenin and its downstream genes in SGC-7901 cells when treated with TSN $(0.5$ and $1 \mu \mathrm{M})$ or TSN $(1 \mu \mathrm{M})$ combined with LV-CTNNB1 transduction. $\beta$-actin was used as the loading control for total protein and histone H3 for the nuclear fractions. (D) OD values of SGC-7901 cells treated by TSN (1 $\mu \mathrm{M})$ or TSN (1 $\mu \mathrm{M})$ combined with LV-CTNNB1 transduction for 24,48 and $72 \mathrm{~h}$ were examined by MTT assay. (E) Cell cycle of SGC-7901 cells treated by TSN ( $1 \mu$ M) or TSN $(1 \mu \mathrm{M})$ combined with LV-CTNNB1 transduction for $48 \mathrm{~h}$ were determined by flow cytometric analysis. (F) Apoptosis rates of SGC-7901 cells treated by TSN $(1 \mu \mathrm{M})$ or TSN $(1 \mu \mathrm{M})$ combined with LV-CTNNB1 transduction for 48 h were determined by flow cytometric analysis. (G) Alterations of invasion were determined by Transwell assay. Representative images of invaded SGC-7901 cells after treatment of TSN ( $1 \mu \mathrm{M})$ or TSN ( $1 \mu \mathrm{M})$ combined with LV-CTNNB1 transduction for $48 \mathrm{~h}$ are shown (red scale bar, $20 \mu \mathrm{m})$. (H) Cell migration of SGC-7901 cells treated by TSN (1 $\mu \mathrm{M})$ or TSN (1 $\mu \mathrm{M})$ combined with LV-CTNNB1 transduction for $72 \mathrm{~h}$ were examined by the wound-healing assay (red scale bar, $200 \mu \mathrm{m}$ ). (I) The effect of LV-CTNNB1 transduction on the alteration of EMT markers expression induced by TGF- $\beta 1(10 \mathrm{ng} / \mathrm{ml})$ combined with TSN (1 $\mu$ M) in SGC-7901 cells as determined by immunoblotting $\left({ }^{*} \mathrm{p}<0.05,{ }^{* *} \mathrm{p}<0.01\right)$.

and reduced by TGF- $\beta 1$ (10 ng/ml), was increased by TSN. TSN also led to significant downregulation of mesenchymal markers (vimentin and $\mathrm{N}$-cadherin) expression elevated by TGF- $\beta 1$ (Fig. 2E).

TSN has antitumor effects on SGC-7901 cells via $\beta$-catenin signaling. We hypothesized effects of TSN on SGC-7901 cells could be mediated by $\beta$-catenin signaling. $\beta$-catenin and its downstream target genes were assessed by qRT-PCR and western blotting. The $\beta$-catenin protein expression (including that in the nucleus) in SGC-7901 cells transfected by LV-CTNNB1 significantly increased comparing with those without transfection (Fig. 3A). TSN could significantly decrease the mRNA and protein levels of genes in $\beta$-catenin pathway ( $\beta$-catenin, c-Myc, cyclin D1, Bcl-2 and MMP-9) in SGC-7901 cells in a dose-dependent manner and exogenous $\beta$-catenin overexpression abolished the effects (Fig. 3B and C). Functionally, increasing the levels of $\beta$-catenin reversed the effects of TSN on biological behavior of SGC-7901 cells, including proliferation, cell cycle progression, apoptosis, invasion, migration and TGF- $\beta 1$-induced EMT (Fig. 3D-I). These findings suggest that TSN might possess antitumor effects on SGC-7901 cells through repressing $\beta$-catenin signaling in vitro. 
A
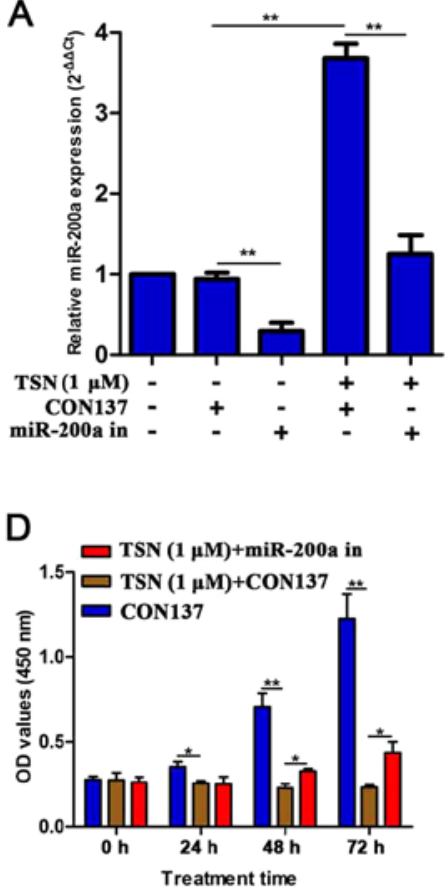

B

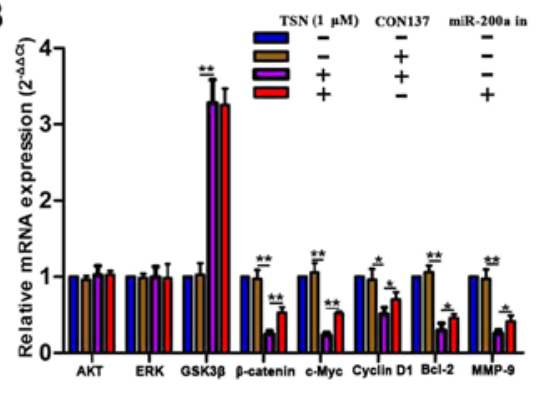

E
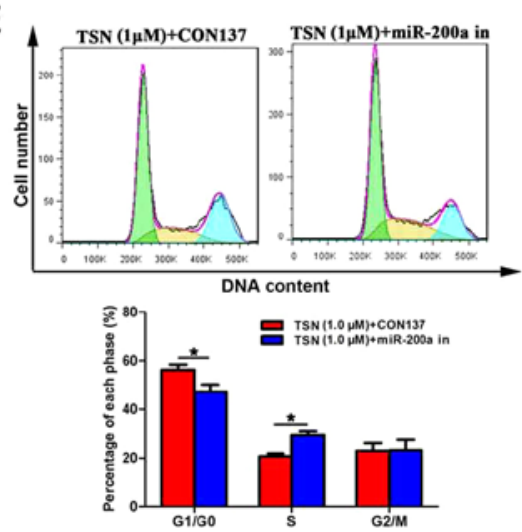
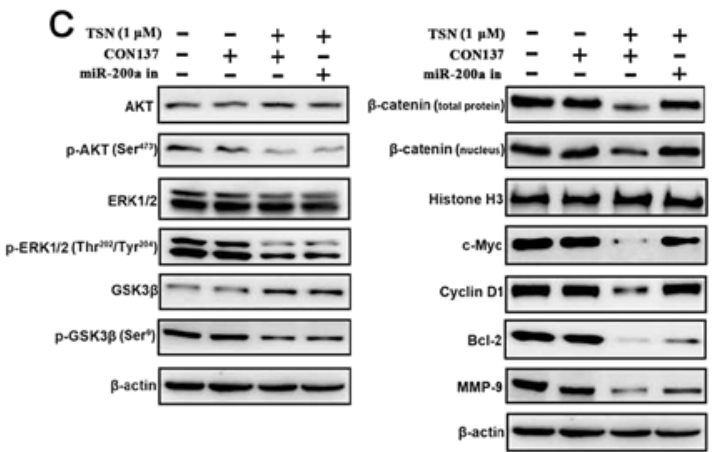

F
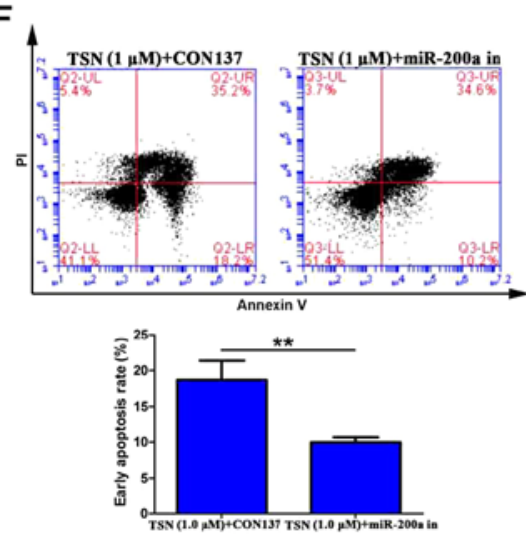

G
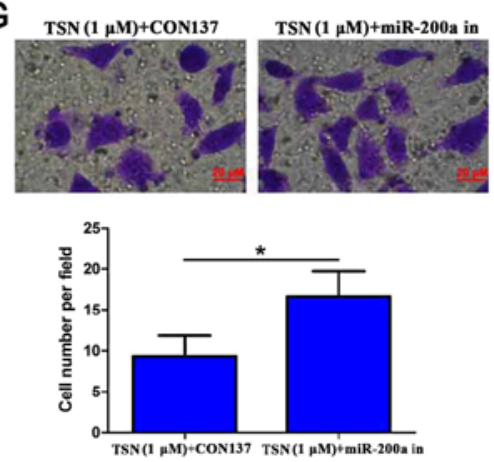

$\mathrm{H}$

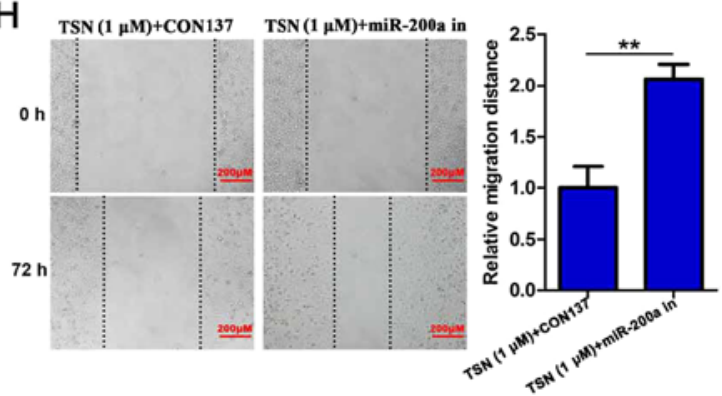

I

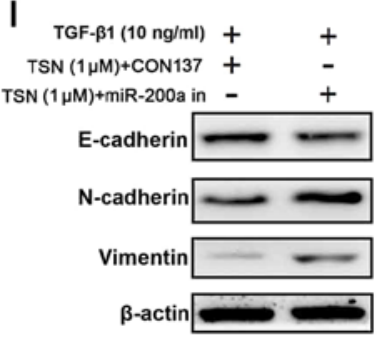

Figure 4. TSN suppresses $\beta$-catenin pathway partly through upregulating miR-200a. (A) qRT-PCR was used to determine the relative expression of miR-200a in SGC-7901-miR-NC and SGC-7901-anti-miR-200a cells treated with or without TSN (1 $\mu \mathrm{M})$. The mRNA (B) and protein (C) expression of genes related to $\beta$-catenin pathway in SGC-7901 cells transfected with LV-hsa-miR-200a-3p-inhibition or CON137 (negative control for LV-has-miR-200a-3p-inhibition) and treated with or without TSN $(1 \mu \mathrm{M}) ; \beta$-actin was used as the loading control for total protein and histone H3 for the nuclear fractions. (D) MTT assay was performed to detect the OD values of SGC-7901 cells treated with miR-200a silencing and TSN $(1 \mu \mathrm{M})$ for 24,48 and $72 \mathrm{~h}$. (E) Cell cycle of SGC-7901 cells treated with miR-200a silencing and TSN $(1 \mu \mathrm{M})$ for $48 \mathrm{~h}$ were determined by flow cytometric analysis. (F) Apoptosis rates of SGC-7901 cells treated with miR-200a silencing and TSN $(1 \mu \mathrm{M})$ for $48 \mathrm{~h}$ were determined by flow cytometric analysis. (G) Alterations of invasion were determined by Transwell assay. Representative images of invaded SGC-7901 cells treated with miR-200a silencing and TSN (1 $\mu \mathrm{M})$ for $48 \mathrm{~h}$ were shown (red scale bar, $20 \mu \mathrm{m})$. (H) Cell migration of SGC-7901 cells treated with miR-200a silencing and TSN $(1 \mu \mathrm{M})$ for $72 \mathrm{~h}$ were examined by the wound-healing assay (red scale bar, $200 \mu \mathrm{m})$ (I) The effect of TGF- $\beta 1(10 \mathrm{ng} / \mathrm{ml})$ combined with TSN $(1 \mu \mathrm{M})$ on the alteration of EMT markers expression in SGC-7901 cells treated with miR-200a silencing as determined by immunoblotting $\left({ }^{*} \mathrm{p}<0.05,{ }^{* *} \mathrm{p}<0.01\right)$.

TSN suppresses $\beta$-catenin pathway partly through upregulating miR-200a. To further verify whether miR-200a mediates the inhibitory effects of TSN on $\beta$-catenin pathway, we established stable SGC-7901 cell lines transfected with LV-hsa-miR-200a-3p-inhibition in which the level of miR-200a was lower compared with that in SGC-7901 cells without transfection (Fig. 4A). After treating for $48 \mathrm{~h}$, TSN dramatically elevated miR-200a expression which was abrogated by miR-200a silencing (Fig. 4A). More importantly, knockdown of miR-200a attenuated suppressive effects of TSN on mRNA and protein expression of $\beta$-catenin, c-Myc, cyclin D1, Bcl-2 and MMP-9 (Fig. 4B and C). Nevertheless, it is worth noting that miR-200a silencing did not influence protein level of upstream regulators of $\beta$-catenin (p-AKT, p-ERK and p-GSK3 $\beta$ ) which were downregulated by TSN (Fig. 4C). Results also showed that the mRNA and protein level of AKT and ERK were not influenced by any of the above treatments. Knockdown of miR-200a did not affect protein level of GSK $3 \beta$ which raised after TSN treatment due to the reduction of p-GSK3 $\beta$ protein level (Fig. $4 \mathrm{C}$ ). Altogether, these data strongly indicated that TSN suppresses $\beta$-catenin pathway by activating AKT and ERK signaling as well as facilitating miR-200a which might only target $\beta$-catenin and then influence its downstream genes. 

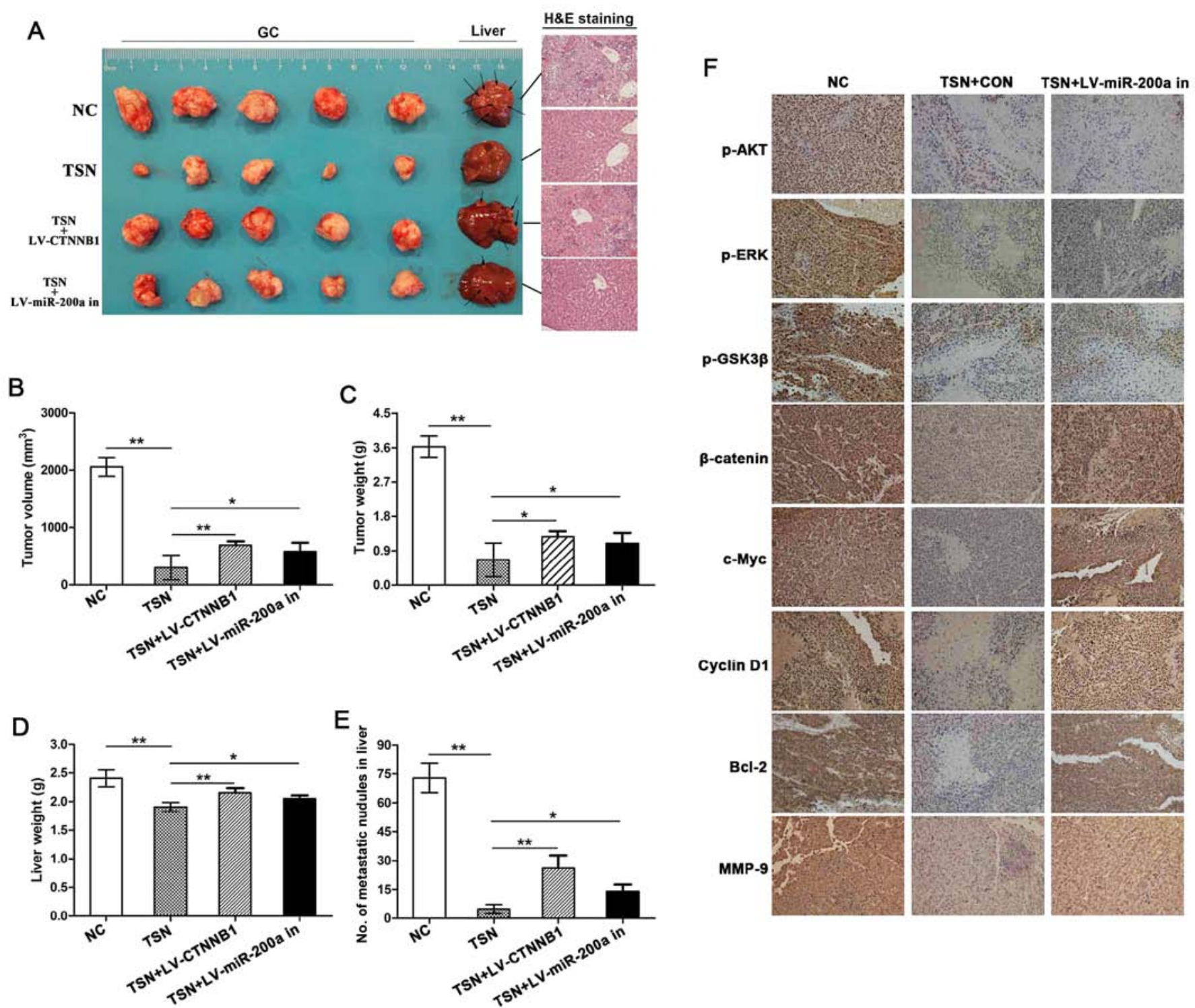

Figure 5. TSN inhibits GC growth and liver metastasis via miR-200a/ $\beta$-catenin axis in vivo. (A) The orthotopically implanted GC and liver tissues from mice in each group were removed and $\mathrm{H} \& \mathrm{E}$ staining was performed to assay the extent of liver metastasis. Liver surface metastatic nodules are indicated by black arrows. The volume (B) and weight (C) of resected GC tissues in different groups. The liver weights (D) and numbers of visible metastatic tumor nodules in liver (E) in different groups. (F) IHC analysis of the expression of proteins related to $\beta$-catenin pathway in GC tissues in different groups ( $\left." \mathrm{p}<0.05,{ }^{* *} \mathrm{p}<0.01\right)$.

TSN-induced impaired biological behaviors of SGC-7901 cells were relieved by miR-200a silencing. To investigate the role of miR-200a in inhibitory effects of TSN on SGC-7901 cells, MTT, flow cytometry, Transwell, wound healing, and western blot analysis were used. Our results displayed that when cells transfected with CON137 (negative control for LV-hsa-miR-200a-3p-inhibition) were exposed to TSN (1 $\mu \mathrm{M})$ for $48 \mathrm{~h}$, significant cell cycle arrest at G0/G1 phase and apoptosis were found as well as decline of proliferation, invasion, migration and TGF- $\beta 1$-induced EMT. Moreover, miR-200a silencing enabled SGC-7901 cells to overcome the above effects of TSN (Fig. 4D-I). Taken together, these findings supported that miR-200a mediated suppressive effect of TSN on $\beta$-catenin pathway and biological behaviors in SGC-7901 cells.

TSN inhibits GC growth and liver metastasis via miR-200a/ $\beta$-catenin axis in vivo. Given that TSN has antitumor effects on
GC in vitro, potential effects of TSN on GC growth and liver metastasis in vivo were further investigated by establishing orthotopic transplantation GC model in nude mice. The results showed that mice administered by TSN had lower average volume and weight of GC tissues, less number of metastatic nodules in liver and lower liver weight than those of animals in control group. More importantly, in groups of models established with SGC-7901 cells transfected with LV-CTNNB1 or LV-hsa-miR-200a-3p inhibition, the above curative effect of TSN was significantly weakened (Fig. 5A-E). In addition, as indicated in Fig. 5F, IHC assay showed that TSN reduced the expression of $\mathrm{p}-\mathrm{AKT}, \mathrm{p}$-ERK, $\mathrm{p}$-GSK3$\beta, \beta$-catenin, c-Myc, cyclin D1, Bcl-2 and MMP-9 in GC tissues. Consistent with observations in vitro, miR-200a depletion abolished suppressive effects of TSN on the above proteins excluding p-AKT, p-ERK and p-GSK3 $\beta$ in tissues. These data provided evidence that TSN inhibits GC growth and liver metastasis via $\mathrm{miR}-200 \mathrm{a} / \beta$-catenin axis in vivo. 


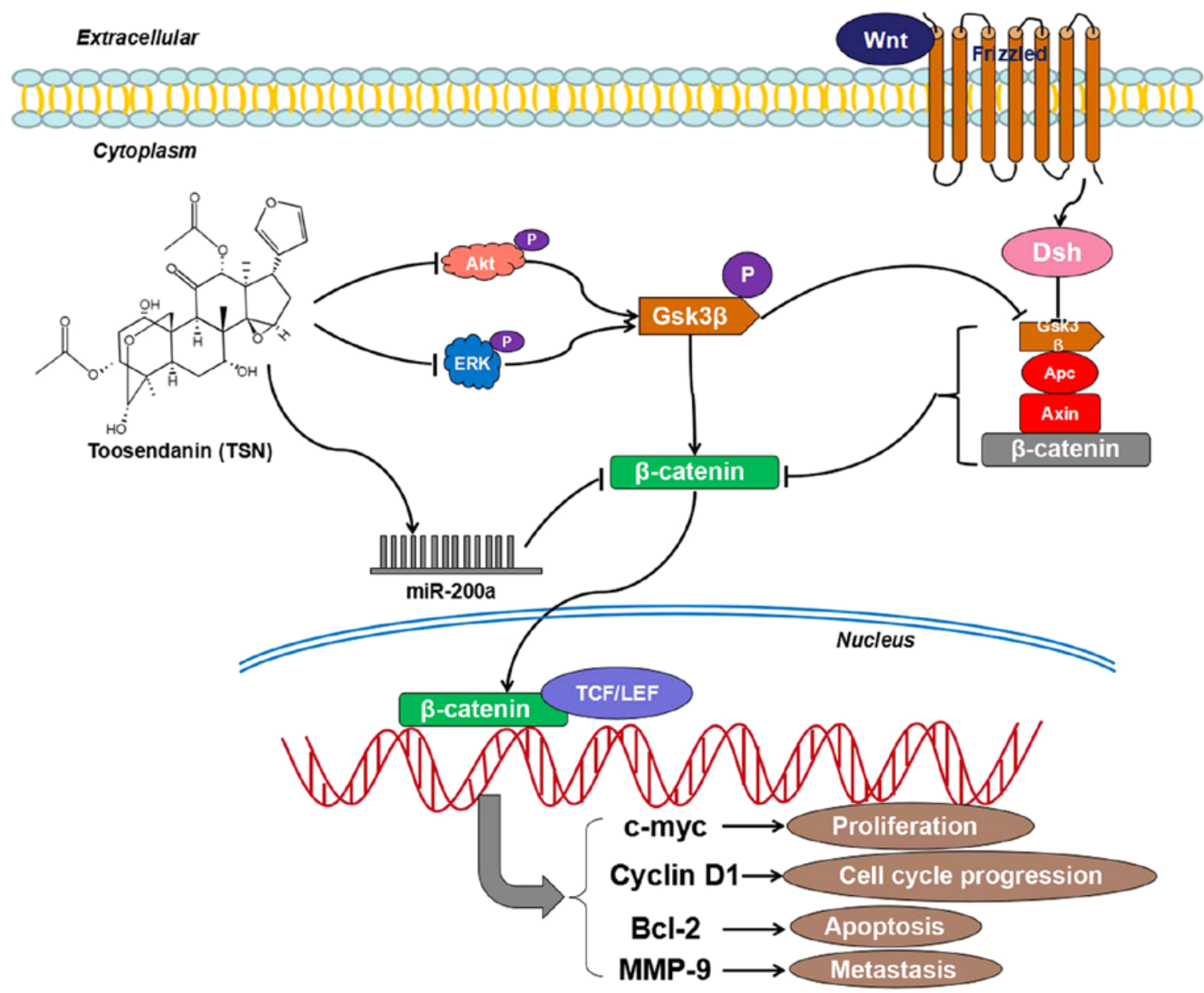

Figure 6. Mechanisms by which TSN suppresses growth and metastasis of human GC SGC-7901 cells. On the one hand, TSN upregulates expression of miR-200a which in turn targets $\beta$-catenin. On the other hand, TSN represses ERK/GSK3 $\beta / \beta$-catenin and AKT/GSK3 $\beta / \beta$-catenin signaling pathways. These two mechanisms both contribute to attenuation of expression of $\beta$-catenin, which in turn reduces level of oncogenes related to growth and metastasis of SGC-7901 cells.

\section{Discussion}

Although progress has been made for GC therapeutic strategy, clinical improvement is still marginal for cancer metastasis and severe drug toxicities and resistance (3). As a result, increasing natural products and their derivatives which have rich structural diversity and promising therapeutic applications have appealed to pharmacologists $(42,43)$. TSN is such a derivative possessing many biological functions including anticancer activity. We have previously reported toxicity of TSN on CRC cells (40) and in this study, TSN inhibited proliferation of a series of GC cells but exerted less cytotoxicity on normal gastric epithelial cell GSE-1. SGC-7901 cells showed the most sensitivity to TSN which suppressed proliferation, arrested cell cycle at G0/G1 phase, induced apoptosis and inhibited invasion and migration of SGC-7901 cells in a dose-dependent manner. Moreover, administration of TSN also significantly inhibited GC growth and liver metastasis in nude mice in vivo. EMT, by which cells lose their epithelial phenotype, and acquire a migratory mesenchymal phenotype, plays a pivotal role in GC migration and invasion $(18,44)$. Transforming growth factor $\beta 1$ (TGF- $\beta 1$ ), a molecular member of TGF- $\beta$ signaling pathway whose dysregulation can result in tumor development, cooperates with signaling pathways, such as Ras and Wnt, to induce
EMT in multiple human cancers (45-47). When gastric cancer cells receive signals from their microenvironment, such as TGF- $\beta 1$, EMT occur and provide cells a distinct advantage in tumor progression and metastasis (48). The present study manifested that TGF- $\beta 1$ could induce EMT in SGC-7901 cells by downregulating epithelial marker E-cadherin expression and upregulating mesenchymal marker $\mathrm{N}$-cadherin and vimentin expression, consistent with previous reports (49-51). TSN treatment reversed the above effects of TGF- $\beta 1$. All these results suggested that TSN inhibited bioactivity of SGC-7901 cells from different angles.

Aberrant activation of Wnt/ $\beta$-catenin pathway can cause uncontrolled cell growth and cell malignant transformation $(8,9)$. The central event is the accumulation of $\beta$-catenin in the cytoplasm followed by translocating into the nucleus, binding with $\mathrm{T}$ cell factor/lymphoid enhancer factor (TCF/LEF)-1 proteins and causing transactivation of downstream target oncogenes such as c-Myc, cyclin D1, Bcl-2 and MMP-9 (52-54). $\beta$-catenin was also found to regulate EMT as an E-cadherin-binding protein involved in the regulation of cell to cell adhesion (55). We have previously found AKT/GSK-3 $\beta /$ $\beta$-catenin pathway mediated inhibitory effects of TSN on CRC cells (40). Herein, we reported that TSN significantly decreased the mRNA and protein levels of $\beta$-catenin, c-Myc, cyclin D1, 
Bcl-2 and MMP-9 in a dose-dependent manner in SGC-7901 cells. Since c-Myc, cyclin D1, Bcl-2 and MMP-9 were closely associated with proliferation, cell cycle progression, apoptosis and metastasis of GC (56-59), we speculated that inactivation of $\beta$-catenin pathway contributed to impaired activities of SGC-7901 cells treated by TSN. Our hypothesis was further verified by gain-of-function analysis which revealed that $\beta$-catenin overexpression reversed the effects of TSN on GC in vitro and in vivo. This evidence supported that TSN exerts antitumor effects on SGC-7901 cells via $\beta$-catenin pathway.

In recent studies, miR-200a was confirmed to be a tumor suppressor and a negative regulator of $\beta$-catenin signaling and $\beta$-catenin mRNA can be downregulated by miR-200a $(24,33,34,60)$. In view of the fact that miRNA can also widely promote target mRNA degradation in animals including human $(61,62)$, the mechanism in it may be related to $\beta$-catenin mRNA degradation by miR-200a which interacted with 3'-UTR of $\beta$-catenin mRNA. Consistent with this, the present study revealed that TSN significantly upregulated level of miR-200a and then decreased $\beta$-catenin mRNA in SGC-7901 cells. In vitro and in vivo findings also showed that knockdown of miR-200a attenuated the inhibitory effects of TSN on mRNA and protein of $\beta$-catenin and its downstream molecules. The reason for this may be that knockdown of miR-200a can weaken the degradation of $\beta$-catenin mRNA which results in increasing level of $\beta$-catenin mRNA and protein. However, silencing of miR-200a only partly reversed suppressive effects of TSN on mRNA expression of $\beta$-catenin. As a result, we speculate that besides miR-200a, other TSN-regulated molecules may also participate in decreased $\beta$-catenin mRNA by TSN treatment. More complicated molecular mechanism involved in it will be explored in the future.

Interestingly, p-AKT, p-ERK and p-GSK3 $\beta$, the upstream regulators of protein of $\beta$-catenin, were also repressed by TSN but not abolished by miR-200a silencing subsequently. The reason for this may be that targets of miR-200a include $\beta$-catenin but not p-AKT, p-ERK and p-GSK3 $\beta$. Taken together, TSN blocked $\beta$-catenin signaling by means, on one hand, of raising expression of miR-200a which in turn targets $\beta$-catenin, on the other hand, by suppressing ERK/ GSK3 $\beta / \beta$-catenin and AKT/GSK3 $/ / \beta$-catenin signaling pathways (Fig. 6). Furthermore, it was observed that knockdown of miR-200a attenuated TSN-induced suppression of biological behavior of SGC-7901 cells in vitro and in vivo. This was consistent with the role of miR-200a/ $\beta$-catenin axis in anticancer effects of TSN on SGC-7901 cells.

In conclusion, our data demonstrated that TSN, derived from Melia toosendan Sieb et Zucc, suppressed GC by inhibiting proliferation, invasion, migration and TGF- $\beta 1$-induced EMT and inducing cell apoptosis and cell cycle arrest. The molecular mechanisms involved may include miR-200a-mediated downregulation of $\beta$-catenin pathway. All these findings highlight the potential of TSN as a chemotherapeutic agent for GC therapy. Notably, $\mathrm{IC}_{50}$ value of GC cells $(0.11-32.71 \mu \mathrm{M})$ was not much lower than that of normal gastric epithelial cells (GES-1, 4.10-60.74 $\mu \mathrm{M}$ ). It indicated the potential side effects of TSN administration such as gastrointestinal reaction in the body. Although obvious adverse reactions in nude mice administrated by TSN $(0.20 \mathrm{mg} / \mathrm{kg} /$ day $)$ were not found in our in vivo study, increased vigilance might be necessary when higher dose of TSN is used. Therefore, pharmacokinetics and toxicology of TSN in vivo are the future research objectives.

\section{Acknowledgements}

This study was supported by National Nature Science Foundation of China (no. 81573747) and Hong Kong Scholars Program (no. XJ2015033).

\section{References}

1. Siegel RL, Miller KD and Jemal A: Cancer statistics, 2015. CA Cancer J Clin 65: 5-29, 2015.

2. Ferlay J, Soerjomataram I, Dikshit R, Eser S, Mathers C, Rebelo M, Parkin DM, Forman D and Bray F: Cancer incidence and mortality worldwide: Sources, methods and major patterns in GLOBOCAN 2012. Int J Cancer 136: E359-E386, 2015.

3. Siegel R, Naishadham D and Jemal A: Cancer statistics, 2013. CA Cancer J Clin 63: 11-30, 2013.

4. Fodale V, Pierobon M, Liotta L and Petricoin E: Mechanism of cell adaptation: When and how do cancer cells develop chemoresistance? Cancer J 17: 89-95, 2011.

5. Croce JC and McClay DR: Evolution of the Wnt pathways. Methods Mol Biol 469: 3-18, 2008.

6. Yu M, Ting DT, Stott SL, Wittner BS, Ozsolak F, Paul S, Ciciliano JC, Smas ME, Winokur D, Gilman AJ, et al: RNA sequencing of pancreatic circulating tumour cells implicates WNT signalling in metastasis. Nature 487: 510-513, 2012.

7. Fu L, Zhang C, Zhang LY, Dong SS, Lu LH, Chen J, Dai Y, Li Y, Kong KL, Kwong DL, et al: Wnt2 secreted by tumour fibroblasts promotes tumour progression in oesophageal cancer by activation of the Wnt/ $\beta$-catenin signalling pathway. Gut 60: 1635-1643, 2011.

8. Clevers $\mathrm{H}$ : Wnt/beta-catenin signaling in development and disease. Cell 127: 469-480, 2006.

9. Logan CY and Nusse R: The Wnt signaling pathway in development and disease. Annu Rev Cell Dev Biol 20: 781-810, 2004.

10. Pinto D, Gregorieff A, Begthel $\mathrm{H}$ and Clevers H: Canonical Wnt signals are essential for homeostasis of the intestinal epithelium. Genes Dev 17: 1709-1713, 2003.

11. Sansom OJ, Reed KR, Hayes AJ, Ireland H, Brinkmann H, Newton IP, Batlle E, Simon-Assmann P, Clevers H, Nathke IS, et al: Loss of Apc in vivo immediately perturbs Wnt signaling, differentiation, and migration. Genes Dev 18: 1385-1390, 2004.

12. Ooi CH, Ivanova T, Wu J, Lee M, Tan IB, Tao J, Ward L, Koo JH, Gopalakrishnan V, Zhu Y, et al: Oncogenic pathway combinations predict clinical prognosis in gastric cancer. PLoS Genet 5: e1000676, 2009.

13. Clements WM, Wang J, Sarnaik A, Kim OJ, MacDonald J, Fenoglio-Preiser C, Groden J and Lowy AM: beta-catenin mutation is a frequent cause of Wnt pathway activation in gastric cancer. Cancer Res 62: 3503-3506, 2002.

14. Ikenoue T, Ijichi H, Kato N, Kanai F, Masaki T, Rengifo W, Okamoto M, Matsumura M, Kawabe T, Shiratori Y, et al: Analysis of the beta-catenin/T cell factor signaling pathway in 36 gastrointestinal and liver cancer cells. Jpn J Cancer Res 93: $1213-1220,2002$.

15. Song X, Xin N, Wang $\mathrm{W}$ and Zhao $\mathrm{C}$ : Wnt/ $\beta$-catenin, an oncogenic pathway targeted by $H$. pylori in gastric carcinogenesis. Oncotarget 6: 35579-35588, 2015.

16. Kolligs FT, Bommer G and Göke B: Wnt/beta-catenin/tcf signaling: A critical pathway in gastrointestinal tumorigenesis. Digestion 66: 131-144, 2002.

17. Polakis P: Wnt signaling and cancer. Genes Dev 14: 1837-1851, 2000.

18. Yilmaz M and Christofori G: EMT, the cytoskeleton, and cancer cell invasion. Cancer Metastasis Rev 28: 15-33, 2009.

19. López-Novoa JM and Nieto MA: Inflammation and EMT: An alliance towards organ fibrosis and cancer progression. EMBO Mol Med 1: 303-314, 2009.

20. Talbot LJ, Bhattacharya SD and Kuo PC: Epithelial-mesenchymal transition, the tumor microenvironment, and metastatic behavior of epithelial malignancies. Int J Biochem Mol Biol 3: 117-136, 2012.

21. Ambros V: The functions of animal microRNAs. Nature 431: 350-355, 2004. 
22. Esquela-Kerscher A and Slack FJ: Oncomirs - microRNAs with a role in cancer. Nat Rev Cancer 6: 259-269, 2006.

23. Zhang B, Pan X, Cobb GP and Anderson TA: microRNAs as oncogenes and tumor suppressors. Dev Biol 302: 1-12, 2007.

24. Liu J, Ruan B, You N, Huang Q, Liu W, Dang Z, Xu W, Zhou T, Ji R, Cao Y, et al: Downregulation of miR-200a induces EMT phenotypes and CSC-like signatures through targeting the $\beta$-catenin pathway in hepatic oval cells. PLoS One 8: e79409, 2013.

25. Chen Z, Saad R, Jia P, Peng D, Zhu S, Washington MK, Zhao Z, $\mathrm{Xu} \mathrm{Z}$ and El-Rifai W: Gastric adenocarcinoma has a unique microRNA signature not present in esophageal adenocarcinoma. Cancer 119: 1985-1993, 2013.

26. Chang L, Guo F, Huo B, Lv Y, Wang Y and Liu W: Expression and clinical significance of the microRNA-200 family in gastric cancer. Oncol Lett 9: 2317-2324, 2015.

27. Barron N, Keenan J, Gammell P, Martinez VG, Freeman A Masters JR and Clynes M: Biochemical relapse following radical prostatectomy and miR-200a levels in prostate cancer. Prostate 72: 1193-1199, 2012

28. Guttilla IK, Adams BD and White BA: ER $\alpha$, microRNAs, and the epithelial-mesenchymal transition in breast cancer. Trends Endocrinol Metab 23: 73-82, 2012.

29. Roybal JD, Zang Y, Ahn YH, Yang Y, Gibbons DL, Baird BN, Alvarez C, Thilaganathan N, Liu DD, Saintigny P, et al: miR-200 Inhibits lung adenocarcinoma cell invasion and metastasis by targeting Flt1/VEGFR1. Mol Cancer Res 9: 25-35, 2011.

30. Shinozaki A, Sakatani T, Ushiku T, Hino R, Isogai M, Ishikawa S Uozaki H, Takada K and Fukayama M: Downregulation of microRNA-200 in EBV-associated gastric carcinoma. Cancer Res 70: 4719-4727, 2010.

31. Cao Q, Mani RS, Ateeq B, Dhanasekaran SM, Asangani IA Prensner JR, Kim JH, Brenner JC, Jing X, Cao X, et al: Coordinated regulation of polycomb group complexes through microRNAs in cancer. Cancer Cell 20: 187-199, 2011.

32. Mateescu B, Batista L, Cardon M, Gruosso T, de Feraudy Y, Mariani O, Nicolas A, Meyniel JP, Cottu P, Sastre-Garau X, et al: miR-141 and miR-200a act on ovarian tumorigenesis by controlling oxidative stress response. Nat Med 17: 1627-1635, 2011.

33. Su J, Zhang A, Shi Z, Ma F, Pu P, Wang T, Zhang J, Kang C and Zhang Q: MicroRNA-200a suppresses the Wnt/ $\beta$-catenin signaling pathway by interacting with $\beta$-catenin. Int J Oncol 40 : $1162-1170,2012$

34. Cong N, Du P, Zhang A, Shen F, Su J, Pu P, Wang T, Zjang J, Kang $C$ and Zhang Q: Downregulated microRNA-200a promotes EMT and tumor growth through the wnt $/ \beta$-catenin pathway by targeting the E-cadherin repressors ZEB1/ZEB2 in gastric adenocarcinoma. Oncol Rep 29: 1579-1587, 2013.

35. Huang K, Zhang JX, Han L, You YP, Jiang T, Pu PY and Kang CS: MicroRNA roles in beta-catenin pathway. Mol Cancer 9: 252, 2010.

36. He Y, Wang J, Liu X, Zhang L, Yi G, Li C, He X, Wang P and Jiang H: Toosendanin inhibits hepatocellular carcinoma cells by inducing mitochondria-dependent apoptosis. Planta Med 76 $1447-1453,2010$

37. Tang MZ, Wang ZF and Shi YL: Involvement of cytochrome $c$ release and caspase activation in toosendanin-induced PC12 cell apoptosis. Toxicology 201: 31-38, 2004.

38. Yu JC, Min ZD and Ip NY: Melia toosendan regulates PC12 Cell differentiation via the activation of protein kinase $\mathrm{A}$ and extracellular signal-regulated kinases. Neurosignals 13: 248-257, 2004

39. Zhang B, Wang ZF, Tang MZ and Shi YL: Growth inhibition and apoptosis-induced effect on human cancer cells of toosendanin, a triterpenoid derivative from Chinese traditional medicine. Invest New Drugs 23: 547-553, 2005.

40. Wang G, Feng CC, Chu SJ, Zhang R, Lu YM, Zhu JS and Zhang J: Toosendanin inhibits growth and induces apoptosis in colorectal cancer cells through suppression of AKT/GSK-3 $\beta / \beta$-catenin pathway. Int J Oncol 47: 1767-1774, 2015.

41. Li Y, Li B, Zhang Y, Xiang CP, Li YY and Wu XL: Serial observations on an orthotopic gastric cancer model constructed using improved implantation technique. World J Gastroenterol 17: 1442-1447, 2011

42. Clardy J and Walsh C: Lessons from natural molecules. Nature 432: 829-837, 2004
43. Mishra BB and Tiwari VK: Natural products: An evolving role in future drug discovery. Eur J Med Chem 46: 4769-4807, 2011.

44. Zhang ZY and Ge HY: Micrometastasis in gastric cancer. Cancer Lett 336: 34-45, 2013.

45. Janda E, Lehmann K, Killisch I, Jechlinger M, Herzig M, Downward J, Beug H and Grünert S: Ras and TGF[beta] cooperatively regulate epithelial cell plasticity and metastasis: Dissection of Ras signaling pathways. J Cell Biol 156: 299-313, 2002.

46. Massagué J: TGFbeta in cancer. Cell 134: 215-230, 2008.

47. Nawshad A, Lagamba D, Polad A and Hay ED: Transforming growth factor-beta signaling during epithelial-mesenchymal transformation: Implications for embryogenesis and tumor metastasis. Cells Tissues Organs 179: 11-23, 2005.

48. Shinto O, Yashiro M, Kawajiri H, Shimizu K, Shimizu T, Miwa A and Hirakawa K: Inhibitory effect of a TGFbeta receptor type-I inhibitor, Ki26894, on invasiveness of scirrhous gastric cancer cells. Br J Cancer 102: 844-851, 2010

49. Zhu Y, Liu Y, Qian Y, Dai X, Yang L, Chen J, Guo S and Hisamitsu T: Research on the efficacy of Celastrus Orbiculatus in suppressing TGF- $\beta 1$-induced epithelial-mesenchymal transition by inhibiting HSP27 and TNF- $\alpha$-induced NF- $\kappa$ B/Snail signaling pathway in human gastric adenocarcinoma. BMC Complement Altern Med 14: 433, 2014

50. Ye Z, Li J, Han X, Hou H, Chen H, Zheng X, Lu J, Wang L, Chen W, Li X, et al: TET3 inhibits TGF- $\beta 1$-induced epithelialmesenchymal transition by demethylating miR-30d precursor gene in ovarian cancer cells. J Exp Clin Cancer Res 35: 72 , 2016.

51. Ma M, He M, Jiang Q, Yan Y, Guan S, Zhang J, Yu Z, Chen Q, Sun M, Yao W, et al: miR-487a promotes TGF- $\beta 1$-induced EMT, the migration and invasion of breast cancer cells by directly targeting MAGI2. Int J Biol Sci 12: 397-408, 2016.

52. Cai $C$ and Zhu $X$ : The Wnt/ $\beta$-catenin pathway regulates selfrenewal of cancer stem-like cells in human gastric cancer. Mol Med Rep 5: 1191-1196, 2012.

53. Park EJ, Chung HJ, Park HJ, Kim GD, Ahn YH and Lee SK: Suppression of Src/ERK and GSK-3/ $\beta$-catenin signaling by pinosylvin inhibits the growth of human colorectal cancer cells. Food Chem Toxicol 55: 424-433, 2013.

54. Cai J, Guan H, Fang L, Yang Y, Zhu X, Yuan J, Wu J and Li M: MicroRNA-374 a activates Wnt/ $\beta$-catenin signaling to promote breast cancer metastasis. J Clin Invest 123: 566-579, 2013.

55. Kikuchi A, Yamamoto H, Sato A and Matsumoto S: New insights into the mechanism of Wnt signaling pathway activation. Int Rev Cell Mol Biol 291: 21-71, 2011

56. Seo JH, Jeong ES and Choi YK: Therapeutic effects of lentivirusmediated shRNA targeting of cyclin D1 in human gastric cancer. BMC Cancer 14: 175, 2014.

57. Burlacu A: Regulation of apoptosis by Bcl-2 family proteins J Cell Mol Med 7: 249-257, 2003.

58. Yang F, Xue X, Zheng L, Bi J, Zhou Y, Zhi K, Gu Y and Fang G: Long non-coding RNA GHET1 promotes gastric carcinoma cell proliferation by increasing c-Myc mRNA stability. FEBS J 281: 802-813, 2014

59. Zhang BG, Du T, Zang MD, Chang Q, Fan ZY, Li JF, Yu BQ, Su LP, Li C, Yan C, et al: Androgen receptor promotes gastric cancer cell migration and invasion via AKT-phosphorylation dependent upregulation of matrix metalloproteinase 9. Oncotarget 5: 10584-10595, 2014.

60. Saydam O, Shen Y, Würdinger T, Senol O, Boke E, James MF, Tannous BA, Stemmer-Rachamimov AO, Yi M, Stephens RM, et al: Downregulated microRNA-200a in meningiomas promotes tumor growth by reducing E-cadherin and activating the Wnt/ beta-catenin signaling pathway. Mol Cell Biol 29: 5923-5940, 2009.

61. Giraldez AJ, Mishima Y, Rihel J, Grocock RJ, Van Dongen S, Inoue K, Enright AJ and Schier AF: Zebrafish MiR-430 promotes deadenylation and clearance of maternal mRNAs. Science 312: 75-79, 2006.

62. Lim LP, Lau NC, Garrett-Engele P, Grimson A, Schelter JM, Castle J, Bartel DP, Linsley PS and Johnson JM: Microarray analysis shows that some microRNAs downregulate large numbers of target mRNAs. Nature 433: 769-773, 2005. 